\title{
Exploring biographical fictions: the role of imagination in writing and reading narrative
}

\author{
Rosalind Barber
}

\begin{abstract}
The creation of a literary biography requires an awareness both of how we construct what we believe we 'know' about a writer, and how the stories we adopt change our reading of their works. Research into the sources used to construct Marlowe's and Shakespeare's biographies supports the conclusion that when writers can no longer create their own stories, those created about them are necessarily fictions, even if delivered under the supposedly more 'factual' genre of biography. Historical biographers construct narrative by imaginative interpretation of evidence. Writers' biographies are commonly written not by historians but by literary critics, who draw extra biographical 'evidence' from interpreting the author's works. But interpreting the works is a highly subjective exercise, and the story we find there may depend upon the story we are looking for. In the process of researching and writing a novel in verse based on Marlovian Theory - the idea that Christopher Marlowe faked his own death, fled to Northern Italy and wrote the works attributed to Shakespeare - the utilisation of Shakespeare's Sonnets to create a new narrative exposes the inherently deceptive nature of poetry. By switching between literal and figurative readings, and emphasising previously overlooked phrases, it is possible to interpret the Sonnets in such a way that they support Marlovian Theory more easily than they support the orthodox narrative.
\end{abstract}

Keywords: biography; narrative; fiction; authorship; Marlowe; Shakespeare

Ever since the linguistic turn of the 1970s, the essentially fictive nature of historical reconstructions has been strongly argued. From Hayden White onwards, sceptical thinkers have argued that history has no more legitimate purchase on the past than any other narrative form (Ankersmit 1989; Jenkins 1991; Munslow 1997; Oakeshott 1983; White 1973). No historiographical account can claim to be objective: historians 'cannot strip themselves of their inherited prejudices and preconceptions ... because the historians' preconceptions and prejudices are what make understanding possible in the first place'(Harlan 1989, 587) ${ }^{1}$. But 
understanding that our predecessors' preconceptions and prejudices have shaped historical accounts might lead us to conclude that we have a responsibility to investigate possible alternative histories. This is especially so in the instance of literary biography, where the personal history we accept for the author has a significant bearing on our interpretation of the texts they have left behind.

Hayden White argued that 'the techniques or strategies that [historians and imaginative writers] use in the composition of their discourses can be shown to be substantially the same'(White 1978, 121) and though the statement might strike some as controversial, a number of historians have come to recognise creative fiction as a valid way of interrogating the past. The methods of creative fiction allow us to escape temporarily from our received histories and bring to light the assumptions that underpin their construction. Through fiction, we have license to construct alternative narratives, rethinking histories so widely assumed to be 'true' that they have not been properly examined in the light of contemporary scholarship. As though trapped in bubbles of earlier, empiricist air, many apparent historical 'facts' turn out to be ungrounded assumptions.

Literary biography and historical fiction depend upon the same source material as the basic information from which to construct a narrative. According to W.V.O. Quine, who proposed the idea of the indeterminacy of theories, 'one evidence source can underwrite many different theories. ${ }^{, 2}$ An experiment by Jerzy Topolski illustrated that the same source material 'may be used to construct various historical accounts of any fragment of the past'(Topolski 1999, 199). This might lead one to conclude, as Beverley Southgate does, that 'the past is anyway promiscuous, and the fact that it will go with anyone in general calls into question its usefulness for anyone in

\footnotetext{
${ }^{1}$ Harlan is summarising Gadamer, H.G. 1989. Truth and method. 2nd rev. ed. / translation revised by Joel Weinsheimer and Donald G. Marshall. ed. London: Sheed and Ward.

${ }^{2}$ Quine cited in Topolski, J. 1999. The role of logic and aesthetics in constructing narrative wholes in historiography. History and Theory 38, no. 2: 198-210.
} 
particular' (Southgate 2005, 92). Yet Southgate goes on to argue for history, which he thinks of as 'a game that we play with the past', as invaluable in understanding ourselves and the present, with historians 'now revealed as themselves the architects and builders of a past that would otherwise remain as inconsequential as any other heap of rubble' (Southgate 2006, 55).

Literary biography, as a subset of historiography, is similarly prone to the subjective interpretation of historical evidence. Like historians, literary biographers are 'mere humans engaged in their own subjective reactions to some few surviving evidential traces'(Southgate 2006, 55). It may be argued that they, differentiated from the biographers of non-literary historical figures, have more than 'traces' from which to create a factual narrative when their subject has left a considerable body of creative work. But the interpretation of an author's literary output for biographical purposes is not only prone to a similar or greater degree of subjectivity than other evidence sources; the interpretation of the subject's writings will depend upon the life narrative already imagined for the author of those works.

In the process of writing a verse novel based on the idea that Christopher Marlowe faked his own death, fled to Northern Italy, and wrote the works attributed to Shakespeare - a work of fiction - research into the lives of the protagonists has revealed the extent to which the traditional biographies of both Marlowe and Shakespeare are also fictions.

Characterisation is an essential ingredient of both novel and biography. If literary biographers are to flesh out their subjects to any satisfactory degree (certainly to the degree that would lead to a plausible and coherent narrative), they can look to only two sources: the works attributed to those authors, and the historical record. Though arguments can be made for the relative merits of both literary output and the more usual historical evidence of document and artefact, no sceptical historian would 
claim either as a source of 'truth'. ${ }^{3}$ Both are equally open to interpretation, and even carefully worded legal documents will support numerous readings, as is apparent in the various scholarly interpretations of Shakespeare's gifting his wife the second best bed. As soon as artefacts or documents are used to create narrative, a fictional element intrudes.

There is considerable crossover between fiction and mainstream literary biography. Park Honan, who has published major biographies of both Marlowe and Shakespeare in the last few years, is particularly adept at novelistic flourishes. A fine example occurs when, strongly implicating Sir Thomas Walsingham in Marlowe's death, he writes:
'Neither vicious nor evil, Thomas might express a worry to a faithful subordinate, in an offhand, implicit way, and then, later, notice that affairs resolved themselves. No doubt, life brings poignant loss. On tragic days, one grieved, one stood in wise, reflective sorrow at a graveside, and then rode back to one's fishponds and profitable pigs, or shot at vile, squealing water rats in black water.' (Honan 2005, 349)

Though scholarly biographers are generally more measured in approach, and less imaginative in writing style, it is nevertheless difficult for a plausible biographical narrative to be assembled without conjecture, speculative gap-filling, and other subjective intrusions. Biography, like fiction, involves arguing a series of logical assumptions, and fiction can be seen as an inevitable by-product of narrative construction. Plausible narrative requires the creation of causal connections between various elements of the story. The author's assumptions about the unknown motivations that move the subject from each piece of evidence to the next, even when not openly suggested, are tacitly incorporated into the narrative structure. As Topolski puts it, '[R]elationships that take place among the elements [of the described

\footnotetext{
${ }^{3}$ As Beverley Southgate puts it, 'With any route to a final truth barred, and with all foundations undermined, our histories are revealed as fragile superstructures, suspended over an abyss.' (Ibid, p.55)
} 
whole] must be imagined by the historian, since causal connections are not part of the data but must be inferred from the sources.'(Topolski 1999, 204) The construction of narrative requires the use of imagination in filling in the gaps where information is (as it invariably is) incomplete, in providing causal connections between events, in constructing a background against which the story is played, and in either explicit or implicit construction of the characters' motivation.

In literary biographies, Marlowe is typically characterised as a hot-headed young man prone to violent outbursts. An analysis of the sources behind this representation of Marlowe show it to be constructed by working backwards from the reported manner of his death, often wrongly described as a 'tavern brawl'. 4 The only three witnesses to this event whose names feature in the inquest document have frequently been described as professional liars; two worked for the Elizabethan Secret Service, and the chief of them, Robert Poley, described by Tudor chronicler William Camden as 'very expert in dissembling' (Camden and Darcie 1625, 134) is on record as saying he is happy to lie, even to the Secretary of State: 'I will swear and forswear myself, rather than I will accuse myself to do me any harm.'(Riggs 2004, 144) ${ }^{5}$

The man meant to have murdered Marlowe, Ingram Frizer, and the second witness, Nicholas Skeres, also worked together as con-men. It seems reasonable, therefore, that any presumptions about Marlowe's character made on the basis of the manner of his death as reported by what Nicholl calls this 'profoundly slippery trio'(Nicholl 2002, 39) should at least be questionable. In modern legal terms, the inquest should be regarded at the very least as unsafe.

On closer examination, however, Marlowe's posthumous reputation for violence appears to have been built not on the inquest report (whose contents were not

\footnotetext{
${ }^{4}$ This phrase appears to have originated with Sidney Lee's 1893 biography of Marlowe for the DNB. Lee's biography was written thirty years before Leslie Hotson unearthed the inquest document.

${ }^{5}$ PRO State Papers SP12 / 282 / 13. The context is described in Riggs.
} 
in the public domain until 1925), but on inaccurate accounts of his death disseminated by puritanical evangelists such as Thomas Beard in his influential religious tract, The Theatre Of Gods Judgements. As Riggs $(2005,342)$ points out, this fictional account of the manner and cause of Marlowe's death seems to be cobbled together, in turn, from some of the accusations of Richard Baines, whose "note containing the opinion of on[e] Christopher Marly concerning his damnable Judgment of Religion, and scorn of Godes word' was a key piece of evidence in the case being built against Marlowe for atheism. Baines was a professional deceiver who worked as a spy and informer. He had displayed personal animosity towards Marlowe when they were arrested together in Flushing sixteen months earlier, and his pronouncements on Marlowe's character are no more likely to be true than the similar statements made by Marlowe's former room-mate Thomas Kyd when tortured.

That confessions made under or as a result of torture are not reliable sources of truth, particularly in the Elizabethan period, is illustrated by Hanson (Hanson 1991); that a man's enemies cannot be relied upon for an accurate assessment of character should be self-evident. Yet biographers have relied upon these sources in order to characterise Marlowe as a man who spoke and acted rashly, in order to construct a coherent narrative for his life in the light of the apparently violent circumstances of his death. Marlowe is routinely characterised as violent enough to deserve, or at least to have provoked, the particular violent end that is accepted for him. ${ }^{6}$

But the circumstances of Marlowe's death - the key source of his violent characterisation - are not open to simple and unequivocal interpretation. Though commentators concur that he was stabbed, the accounts of his death circulating in the first hundred years after the event vary considerably, with apparent uncertainty as to

\footnotetext{
${ }^{6}$ David Riggs (2004) notably avoids this pitfall, as do Constance Brown Kuriyama, Virginia Stern and A.D.Wraight. See Kuriyama, C.B. 2002. Christopher marlowe : A renaissance life. Ithaca, London: Cornell University Press., Wraight, A.D. and V.F. Stern. 1965. In search of christopher marlowe; a pictorial biography. London: Macdonald.
} 
whether the stabbing is to the head or to the eye, whether there are one or two knives involved, whether the knife that killed Marlowe was his own or his assailant's. The death is said to have occurred 'in London streets'(Beard 1597, 148) or 'at Detford, a little village about three miles distant from London'(Vaughan 1608, C5). The assailant is described variously as 'one whom he met in a streete in London'(Rudierde 1618, XXII, 29), 'one whome hee ought a grudge unto' and 'purposed to stab'(Beard 1597, 148); 'a bawdy Serving man, a rival of his in his lewde love'(Meres 1598, 286) and more accurately, 'one named Ingram'(Vaughan 1608, C5). So readily did myths and fictions spring up around Marlowe's death that his killer was even identified by John Aubrey as Ben Jonson (Aubrey and Clark 1898, II, 13). ${ }^{7}$

Modern biographers are no less prone to fictional constructions. Many, working backwards from his murder, assume his violent tendencies from the outset, using Marlowe's minor brushes with the law to support this conclusion, though careful consideration of each incident in context fails to show him as the aggressor, and he was never convicted of any crime. In the context of young Elizabethan manhood, it can be argued that Marlowe was considerably less violent than his peers. Ben Jonson, who is not generally characterised as violent, nevertheless 'killed two men for no apparent reason, went to prison on three separate occasions, was "almost at the Gallowes" and wore the brand of a convicted murderer on his thumb' (Riggs 1989, 3).

The general perception of Marlowe as the 'bad boy' of Elizabethan literature derives chiefly from sketches of Marlowe contained in the tortured Kyd's letters to Lord Keeper Puckering, the Baines note, and an anonymous informer's 'Remembrances', which Nicholl argues persuasively were penned by the 'notorious

\footnotetext{
${ }^{7}$ Jonson killed Gabriel Spencer, but did not, so far as we know, stab Marlowe.
} 
rogue' Thomas Drury. ${ }^{8}$ There is considerable reason to doubt the veracity of every one of these documents, particularly given the strong possibility that Marlowe was working as a projector. Projectors in the Queen's service were often mistaken for traitors and sometimes executed; for those working in the fledgling secret service, being arrested and imprisoned as a traitor was an occupational hazard.

Some documentary evidence from Marlowe's life is less ambiguous - we can at least determine his presence at Cambridge, and long unexplained periods of absence, from the college buttery accounts, for example. We also have the unusual intervention of the Privy Council on the $29^{\text {th }}$ June 1587 , insisting the University award his MA despite these absences and a rumour that he 'was determined to have gone beyond the seas to Reames' (the Roman Catholic seminary). A letter signed by the Lord Chancellor, Lord Treasurer, Lord Chamberlaine, Sir William Knollys and the Archbishop of Canterbury, reveals that Marlowe 'had done her Majestie good service, and deserved to be rewarded for his faithfull dealinge', and that 'it was not her Majesties pleasure that anie one emploied as he had been in matters touching the benefitt of his countrie should be defamed by those that are ignorant in th'affaires he went about.' By the age of twenty-three, Marlowe was already attracting rumour; his character, even then, being mistaken, and his actions misinterpreted.

The number of extant documents that can be used to build the basic structure of a biographical narrative are considerably more in Shakespeare's case than in Marlowe's, firstly because the latter had his professional career curtailed, and secondly because Shakespeare involved himself in numerous business dealings. But all of the seventy-plus documents relating to Shakespeare the man (rather than

\footnotetext{
${ }^{8}$ For Drury as author of 'Remembrances' see pp 370-284 of Nicholl, C. 2002. The reckoning : The murder of christopher marlowe. Revised ed. London: Vintage. Drury is described as a 'notorious rogue' by his own nephew (Nicholl 2002, 385) and 'a man of mean condition and notoriously evil character' by Attorney General Coke, who calls his witness statement in a 1603 Star Chamber case 'not worth a frieze jerkin.' (Nicholl 2002, 398)
} 
Shakespeare the author) are of a legal nature and consequently, barring what we might surmise from the various clauses of the infamous will, are unhelpful in the construction of character. In Shakespeare's Unorthodox Biography (Price 2001), Diana Price demonstrates that Shakespeare is unique among writers of his period in leaving no literary paper trail, and that he has also left little or nothing in the way of personal testimony. ${ }^{9}$ Following Honigmann, who demonstrated that the myth of 'sweet Shakespeare' arose out of references to his writing style, as in Meres's 'sugred sonnets'(Honigmann 1982), Price shows that literary allusions to Shakespeare used by biographers to characterise him are references to the works rather than the man (Price 2001, 137).

Characterisation is an essential step towards constructing a plausible narrative, and in the absence of sufficient documentary evidence to support characterisation, it is necessary for literary biographers, scholars and novelists to turn to the works.

Determining an author's character from their plays, however, is problematic.

Drama is necessarily dialectical, and it is not easy to discern the author's views as distinct from the views expressed by the characters. Shakespeare's plays owe some of their continued popularity to the fact that the views of opposing characters are espoused with equally fluent and persuasive rhetoric, so that it is uncertain which characters' views might have been shared by the author. Consequently, many of the plays can be adapted to suit even wildly opposing ideologies. Jonathan Bate notes how, in 1934, a French production of Coriolanus was perceived as proto-fascist, and

\footnotetext{
${ }^{9}$ In her Appendix Chart of Literary Paper Trails, ten categories of evidence (that the subject of investigation was a writer) are logged by Price. Ranked from most to least surviving evidence: Ben Jonson (10), Thomas Nashe, Phillip Massinger, Gabriel Harvey, Edmund Spenser, Samuel Daniel, George Peele, Michael Drayton, George Chapman, William Drummond, Anthony Mundy, John Marston, Thomas Middleton, John Lyly, Thomas Heywood, Thomas Lodge, Robert Greene, Thomas Dekker, Thomas Watson, Christopher Marlowe, Francis Beaumont, John Fletcher, Thomas Kyd, and John Webster (3). There is no evidence of a literary paper trail for Shakespeare in any of the ten categories. In the case of personal testimony, Price makes a clear and careful distinction between personal, impersonal and ambiguous testimony.
} 
that the following year, the same play was staged in Moscow as a morality play for socialists, with Coriolanus as 'enemy of the people'(Bate 2007).

The dialectical nature of drama is a considerable challenge to those wishing to mine the author's plays for character research. Poetry, with its closer (though still ambiguous) relationship to autobiography, appears a more promising avenue to explore.

Though some scholars argue that Shakespeare's sonnets should not be read biographically, but seen rather as a response to, and product of, the Elizabethan vogue for sonneteering, there is a long history of scholarly attempts to interrogate the sonnets for biographical detail. Paul Edmondson \& Stanley Wells, having reviewed both sides of the argument, conclude: '[T]hough Shakespeare's sonnets, like all his work, unquestionably reflect his reading, and though not all of them are intimate in tone, it is not unreasonable to look in them for reflections of his personal experience' (Edmondson and Wells 2004). Thus the 'fair youth' to whom it is widely believed the majority of the sonnets are addressed is identified by a consensus of scholars as a young nobleman, possibly either Henry Wriothesley, the Earl of Southampton, or William Herbert, the Earl of Pembroke. There have also been persistent attempts to identify the 'dark lady' and the 'rival poet'. ${ }^{10}$

Some editors have found the apparent narrative of the sonnets confusing or bothersome, and so have attempted to alter both its focus and course by changing the order in which the sonnets are presented (Duncan-Jones 1997a, 41-44). A biographical reading of the sonnets has led to some readers, from the $19^{\text {th }}$ Century onwards, having difficulty reconciling the poems to what is known, or at least what is believed, of the life of William Shakespeare. Generally, scholars have been mystified

\footnotetext{
${ }^{10}$ These attempts hit scholarly impasse more than half a century ago. When Roland Barthes declared the Author dead, further attempts to identify this author's friends were abandoned with a sense of relief. If the author was dead, then his friends certainly didn't matter.
} 
as to the cause of certain strong emotions that recur through the poems: emotions not reconcilable with the known life of the putative author. Nineteenth century scholars, and Shakespeare-lovers in the wider community, have sometimes been dismayed by the apparently homoerotic content.

But if we are to follow the demands of the Marlovian authorship scenario, any elements of character surmised through interpretation of the Works must be discounted as aspects of Shakespeare's character, and become aspects of Marlowe's. Richard Slotkin, proposing the writing of historical fiction as a useful tool for testing historical hypotheses, lays down the ground rules: 'For the thought-experiment to work, the fiction writer must treat a theory which may be true as if it was certainly true, without quibble or qualification; and credibly represent a material world in which that theory appears to work' (Slotkin 2005, 221). Without at this stage committing to the proposition that Marlowe as the author of Shakespeare's sonnets is something that 'may be true', the results of applying Marlowe's authorship to the sonnets - a useful 'thought-experiment' in the process of creating the work of fiction are interesting.

The first noticeable effect is that the homoerotic content of the sonnets is no longer surprising. Marlowe's sexuality has been the subject of considerable debate, and though it is not useful to apply modern concepts of homosexuality to an era where unmarried men customarily shared beds with each other for practical reasons, there is undoubtedly homoerotic content, or the depiction of homosexual relationships, in three of Marlowe's attributed works: Dido Queen of Carthage, Edward II and the long narrative poem Hero \& Leander. 
Read from the perspective of the Marlovian narrative, the group of poems sometimes referred to as the sonnets of separation become sonnets of exile. ${ }^{11}$ Their allusions to travel ${ }^{12}(27: 2,34: 2)$, a journey undertaken with heavy heart (50:1), a physical separation, sundry losses (34:10) and things lacked (31:2) down to the shape of familiar birds and flowers (113:6) - 'th'expense of many of a vanished sight'(30:8) - can now be read as allusions to Marlowe's long journey on horseback ${ }^{13}$ across Europe to a final destination in foreign climes (in the case of the Marlovian narrative, Northern Italy). Sonnet 50, 'How heavy do I journey on my way', can be taken as expressing an exile's reluctance to continue on a journey in which 'my grief lies onwards and my joy behind.' The 'large lengths of miles' (44:10) are referred to as an 'injurious distance'(44:2), the poet as being in 'limits far remote' (44:4). But the friend is constantly in his thoughts: 'thyself away, art present still with me' (47:10). Sonnet 45 can be read as describing an exchange of letters: the joy of receiving one, swiftly followed by despair when the reply is sent and the wait for a new missive begins:

'oppressed with melancholy, Until life's composition be recurred By those swift messengers returned from thee Who even but now come back again assured Of thy fair health, recounting it to me. This told, I joy; but then no longer glad, I send them back again and straight grow sad.'(45:8-14)

Katherine Duncan-Jones admits the possibility of physical letters, but favours a more metaphorical reading, with the messengers being 'reciprocal sentiments' presumably because we know of no journey of any distance being undertaken by William Shakespeare that would lead to an exchange of letters of this sort (the

\footnotetext{
${ }^{11}$ The parallels between the narrative of the Sonnets and the presumed biography of Marlowe-in-hiding was first noted by Webster, A. 1923. Was marlowe the man? The National Review LXXXII: 81-86. The idea has been further developed by others, notably Wraight, A.D. 1994. The story that the sonnets tell. London, UK: Adam Hart.

${ }^{12}$ Q: travaille: travel, labour. No distinction was made in Elizabethan spelling between the two, and as the sonnets reference both journeying and 'toil', it can be taken to mean either, or more likely both.

${ }^{13}$ See Sonnet 51.
} 
distance between Stratford and London, 100 miles, could be walked in four days). The decision of whether to interpret an image literally or metaphorically depends on the narrative chosen to decode it.

Similarly, the 'suborned informer' (false witness, or hired spy) in Sonnet 125, which some commentators have read as a cryptic reference to a real individual, but which Duncan-Jones believes refers to 'Time' whom she calls 'the explicit addressee of sonnets $123-5^{\prime}$, despite the fact that only the first of those sonnets explicitly addresses Time. Adopting Marlovian narrative gives us the biographical basis for a literal reading, and we may assume it is Richard Baines that Marlowe is addressing when he writes

'Hence, thou suborned informer, a true soul When most impeached, stands least in thy control. ' (125:13-14)

A similar difference in approach can be taken to the line in sonnet 62 where the poet describes himself as being 'Beated and chopped with tanned antiquity'. Duncan-Jones' gloss on this line suggests that 'since Shakespeare's father was a whittawer, who prepared leather for gloves, Shakespeare may well have believed his own skin to have undergone this process', but in the light of the Marlovian narrative, the line can be read as the poet becoming literally weather-beaten as he travels towards Italy. Under this reading, 'whatsoever star that guides my moving' (26:9) could be taken as Fate not simply determining the course of a particular life, but a physical journey as well.

'[T]his separation' (39:7) leads to 'absence' (39:9), to the two friends being 'twain'(36:1, 39:13), a situation the poet appears in various sonnets to rationalise (e.g. 'For thy sweet love remembered such wealth brings' 29:13), or try to come to terms with (e.g. 'let us divided live' 39:5). 
In the Marlovian scenario, given that a person suspected of 'Heresie, Atheisme or Apostacie' in 1593 could be executed without evidence (Shagan 2004, 559) and he was unlikely to escape the charges in the Baines note, Marlowe's death has been faked and - assisted by his secret service colleagues - he has escaped to the continent while on bail. Sonnet 29, immediately following two 'journey' sonnets, can be read as explicitly referring to his state of exile:

'When in disgrace with fortune and men's eyes

I all alone beweep my outcast state,

And trouble deaf heav'n with my bootless cries, And look upon myself, and curse my fate...' (29:1-4)

Christopher Marlowe, the poet and playwright of acknowledged genius, is

'The prey of worms, my body being dead,

The coward conquest of a wretch's knife' (74:10-11).

Richard Baines, whose note to the Privy Council suggested 'all men in christianitei ought to endevor that the mouth of so dangerous a member may be stopped' has effectively prevailed. Marlowe will not write as Marlowe again. And yet he fears even his writing style might give away his anonymity, since he continues to write 'still all one, ever the same... That every word almost doth tell my name' $(76: 5,7)$.

With the name of Marlowe effectively dead, the exiled poet lives only through his writing, and - vicariously - through his friend:

\footnotetext{
'You are my all-the-world, and I must strive To know my shames and praises from your tongue; None else to me, nor I to none, alive.' (112:5-7)
}

Again, the orthodox reading takes this as metaphorical; the Marlovian reading makes it literal. But where a reading may be either metaphorical or literal, the Marlovian reading is not always the literal one. An example is Sonnet 48.

\footnotetext{
'How careful was I, when I took my way, Each trifle under truest bars to thrust, That to my use it might unused stay From hands of falsehood, in sure wards of trust; But thou, to whom my jewels trifles are, Most worthy comfort, now my greatest grief, Though best of dearest, and mine only care, Art left the prey of every vulgar thief.' (48:1-8)
} 
Duncan-Jones's gloss for line 5 says 'To a wealthy young nobleman, the valuables of a professional playwright would no doubt seem trifling.' But reading the sonnets as letters home from exile, sent to a loved one, the 'trifles' entrusted to the friend - the poet's jewels - are the sonnets themselves, and the friend has been inadvisably sharing them. This would chime both with Francis Meres' 1598 mention of Shakespeare's 'sugred sonnets' being shared amongst his friends, and the publication of two of the sonnets in Jaggard's Passionate Pilgrim in $1599 .{ }^{14}$ The poet is concerned that it is the friend who will be put in danger:

'And even thence thou wilt be stol'n, I fear;

For truth proves thievish for a prize so dear.' (48:13-14)

Far from being a sonnet referring to 'the security of his earthly possessions'

(Duncan-Jones 1997a), sonnet 48 can now be read as a warning to a friend who is literally giving too much away.

When reading the sonnets as a narrative of exile, it is possible to detect a note of despair verging at times on the suicidal $(32: 1 ; 66: 1)$. Mining recent personal experience for his metaphor, the poet in the Marlovian narrative begins Sonnet 74:

'But be contented when that fell arrest Without all bail shall carry me away' (74:1-2)

His lost name plagues him in these moribund contemplations, and is linked with a concern to protect his friend, who cannot be discovered to be associated with him:

'When I, perhaps, compounded am with clay,

Do not so much as my poor name rehearse [...]

Lest the wise world should look into your moan,

And mock you with me after I am gone.' (71:10-14)

The name that should not be rehearsed comes up again in the following sonnet:

'My name be buried where my body is,

And live no more to shame nor me, nor you.' (72:11-12)

The nature of the shame is elusive in the orthodox narrative, but in the Marlovian one we have a clear cause. Sonnet 111, which 'has been frequently read as

\footnotetext{
${ }^{14}$ Duncan-Jones discerns a possible allusion to Passionate Pilgrim in Sonnet 112: 'Your love and pity doth th'impression fill/Which vulgar scandal stamped upon my brow.' But if Marlowe's biography provides a powerful 'vulgar scandal' of his own making.
} 
an allusion to Shakespeare's public profession as an actor-dramatist' by orthodox scholars, bears a stronger reading when it relates to Marlowe, whose posthumous reputation was destroyed by those such as Beard:

'Thence comes it that my name receives a brand, And almost thence my nature is subdued To what it works in, like the dyer's hand; Pity me, then, and wish I were renewed'(111:5-8)

As a result of his 'harmful deeds' as government agent, his nature is 'subdued/To what it works in' - to words. Writing is his only way of communicating with the world from which he is exiled.

But writing is also his strength, and from a position of exile he not only gains perspective but a greater depth of thought: 'Ruin hath taught me thus to ruminate' (64:11). The celebration of writing as both powerful and redemptive is a theme to which the sonnets repeatedly return:

'... unless this miracle have might:

That in black ink my love may still shine bright.' $(65: 13-14)^{15}$

Yet time to 'ruminate' brings the poet to negative thought as much as to positive, and twice the poet echoes the Latin inscription on the putative Corpus Christi portrait of Marlowe:

'consumed with that which it was nourished by' (73:12);

and 'the worst was this: my love was my decay' $(80: 14) .{ }^{16}$

He also continues to be bothered by the slurs on his reputation, at times so bitterly that he begins sonnet 121

''Tis better to be vile than vile esteemed'

and ends it

\footnotetext{
${ }^{15}$ See also sonnet 81 and the numerous sonnets addressing the theme of poetry as immortalization, of which Erne counts 'no fewer than twenty-eight'. Erne, L. 2003. Shakespeare as literary dramatist. Cambridge, UK ; New York: Cambridge University Press.

${ }^{16}$ The latin inscription on the 1585 Corpus Christi portrait, which gives the sitter's age as 21 , is QUOD ME NUTRIT ME DESTRUIT; what nourishes me destroys me.
} 
'All men are bad, and in their badness reign.'

The badness of the world is associated explicitly with slander in Sonnet 150:

'Now this ill-wresting world is grown so bad,

Mad slanderers by mad ears believed be.' (150: 11-12)

Sonnet 66 now becomes a much more personal diatribe than the orthodox

narrative allows, with several of the lines appearing to apply directly to the exiled poet's situation: ${ }^{17}$

'...And right perfection wrongfully disgraced,

And strength by limping sway disabled,

And art made tongue-tied by authority,

And folly, doctor-like, controlling skill...' (66:7-10)

In the Marlovian narrative, William Shakespeare is the frontman for the poet's work, and under this reading, 'gilded honour shamefully misplaced' could be taken as an allusion to Shakespeare's being mistaken as the author.

The limping mentioned here is a repeated metaphor that has, with the exception of René Weis (Weis 2007), been largely overlooked by orthodox

Shakespearean scholars; elsewhere, the poet refers to himself as being 'made lame by fortune's dearest spite' (37:3). ${ }^{18}$ Fortune's spite appears again in sonnet 90:

'Then hate me when thou wilt, if even now,

Now while the world is bent my deeds to cross.

Join with spite of fortune, make me bow.' $(90: 1-3)^{19}$

The speaker considers himself deeply unlucky, and feels the world has turned against him, misinterpreting his deeds. This, an aspect of the sonnets that has often perplexed those reading from the orthodox perspective, fits perfectly with the Marlovian one.

Other long-standing interpretive problems dissolve on adopting Marlovian authorship theory. The 'paradoxical claim that [Shake-speare's Sonnets] will be remembered for its subject-matter (the fair youth), not for its author' which is 'taken to its furthest extremes' in Sonnet 81 (Duncan-Jones 1997a, 272) ceases to be any

\footnotetext{
${ }^{17}$ Duncan-Jones glosses this sonnet 'Weary of the corruption and hypocrisy of the age he lives in, the speaker longs for death, restrained only by the thought of abandoning his love.'

${ }^{18}$ Weis, reading the image literally, has concluded that Shakespeare was physically lame.

19 'Spite' makes another appearance in sonnet 36: 'in our lives a separable spite'.
} 
kind of paradox when we adopt the Marlovian narrative. Though the name

'Shakespeare' became very well known, the author behind the name recognised he would not be credited. ${ }^{20}$ The two sonnets that pun on the word, and the name, 'Will', can be read as the poet's attempt to fully inhabit his pseudonym so that he feels less disempowered and over-looked:

'Think all but one, and me in that one Will.' (135:14)

'Make but my name thy love, and love that still;

And then thou lov'st me, for my name is Will.' (136:13-14)

The rival poet referred to in sonnet 86 , who cannot be unequivocally identified in the orthodox narrative, can be confidently identified as George Chapman in the Marlovian one. Previous scholars, starting with William Minto in 1874, have suggested Chapman as the Rival Poet (Acheson 1903; Minto 1874, 222; Robertson 1926), but since no direct link could be found between Chapman and Shakespeare, the presumed author of the sonnets, no consensus could be reached. Chapman, however, had a clear relationship not only to Marlowe but to Marlowe's patron and friend Thomas Walsingham. In 1598 Chapman revised, extended and had published Marlowe's unfinished Hero \& Leander, contributing more lines than Marlowe had written, altering the poem's structure, and dedicating it to Thomas Walsingham's wife, Audrey. Having one's poetic creation taken over would be cause for jealousy enough without the added complication that Chapman appears to have become Marlowe's friend and patron's new favourite. Chapman claimed to have been visited by the spirit of Homer whilst translating his Seauen bookes of the Iliades of Homere, published, like Hero and Leander, in 1598 (Chapman 1941, 174.II.76-77). His identity seems certain when we imagine it is the 'dead' Marlowe who asks

\footnotetext{
${ }^{20}$ Even the name Marlowe, associated as it was with a 'vulgar scandal', was doomed to be forgotten by literary history for over 300 years. In 1820, one critic even unwittingly reversed Marlovian authorship theory by describing Marlowe as 'a borrowed designation of the great Shakespeare'. See Maclure, M. 1979. Christopher marlowe: The critical heritage. London: Routledge.
} 
'Was it his spirit, by spirits taught to write

Above a mortal pitch, that struck me dead?' (86:5-6)

Under this narrative the identification of the rival poet as George Chapman is unproblematic because we have a proven biographical parallel with the situation described in the sonnets. Walsingham patronised and formed close relationships with both Marlowe and Chapman. Viewed through this biographical frame, at least fifteen sonnets (78 to 92), and possibly more, are addressed directly to Walsingham ('both your poets', Sonnet 83 ). When reading the sonnets, there are numerous important interpretative decisions that are wholly dependent on the assumed biography of the author behind the works.

Editorial emendations are similarly dependent on the acceptance of a particular narrative. For example, where some editors have emended Quarto's 'loss' in 34:12 to 'cross', Duncan-Jones rejects this on the basis that it 'transforms the speaker into a Christ-figure', but for the Marlovian narrative this would be preferable, since it chimes with Marlowe's Christian name, which means 'bearing Christ'. ${ }^{21}$ Editors have revised the punctuation of 81:6 such that it reads 'Though I, once gone, to all the world must die', but the Quarto version 'I (once gone)' would work better for the Marlovian narrative, adding to the more obvious meaning (which the revised punctuation makes emphatic) a pun on Marlowe, thought dead, being already 'once gone'. Similarly, in sonnet 113, the Quarto text argues that the poet's eye is effectively blind 'For it no form delivers to the heart/Of bird, or flower, or shape which it doth lack.' Duncan-Jones has accepted Capell's ${ }^{22}$ emendation of 'lack' to 'latch' (grasp, seize with the mind), but if it were understood that the poet had moved to another country, with differing flora and fauna, Quarto's 'lack' might stand.

\footnotetext{
${ }^{21}$ See also 42:12: 'And both for my sake lay on me this cross.'

${ }^{22}$ Edward Capell's marked up copy of Sonnets published by Bernard Lintott (1711), in the Library of Trinity College, Cambridge, is one of the editions of Shakespeare collated by Katherine Duncan-Jones.
} 
Another editorial amendment illustrates even more strongly how one possible narrative might be concealed by the adoption of another. The final couplet of Sonnet 112 reads, in the Quarto:

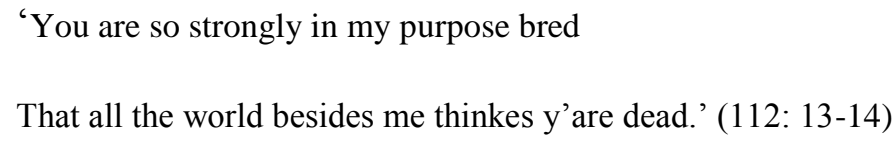

This is frequently emended to 'That all the world, besides, methinks, are dead' but as Duncan-Jones comments, 'none of the proposed emendations ... yields easier sense' than to read 'y'are' as 'you are'. Since the traditional narrative does not allow easy understanding of this couplet, her paraphrase is nevertheless torturous: '(because I have excluded the rest of the world from my consciousness) I believe that to everyone except me you are dead - you have existence only for me.' The Marlovian narrative, however, allows the couplet to be understood very plainly, if we read it as addressed to Thomas Walsingham, whose regular attendance at court ceased after Marlowe's apparent death. Under this narrative, the couplet's meaning is: 'All the world besides you thinks I'm dead. And you're so protective of my secret that you have also dropped from view.'

The Marlovian narrative can account for many of the apparent inconsistencies in the sonnets. For example, it gives a rationale for the poet claiming to have been silenced ('As victors of my silence cannot boast' $86: 11$ ) when he is clearly still writing. It can also elucidate the precise nature of the addressee's offence in sonnets 33-36. In the orthodox narrative, there appears to be some confusion about the 'stain'(33:14) 'shame'(34:9) and 'disgrace'(33:8, 34:8) which, via the poet's apparent forgiveness in sonnet 35 , become 'those blots that do with me remain', so that by sonnet 36, the 'shame' is now associated with the poet (36:10). Edmondson \& Wells note the direct diction employed 'in what seems like a lover's quarrel' and DuncanJones, trying to find clarity of meaning in the orthodox narrative, suggests ' $[\mathrm{t}] \mathrm{he}$ 
young man has wronged his friend; in making excuses for him the poet colludes with him and shares his fault.'

Read from the perspective of Marlowe in exile, a richer story emerges. Here is Sonnet 34 in full.

\footnotetext{
'Why didst thou promise such a beauteous day And make me travail forth without my cloak, To let base clouds o'ertake me in my way, Hiding thy brav'ry in their rotten smoke?

Tis not enough that through the cloud thou break, To dry the rain on my storm-beaten face, For no man well of such a salve can speak That heals the wound and cures not the disgrace; Nor can thy shame give physic to my grief; Though thou repent, yet I have still the loss; Th'offender's sorrow lends but weak relief To him that bears the strong offence's cross. Ah, but those tears are pearl which thy love sheds, And they are rich, and ransom all ill deeds.'
}

In the Marlovian scenario, the friend was instrumental in Marlowe's planned escape, but did not foresee the consequences: the damage to Marlowe's reputation after his apparent death in a knife-fight. The 'rotten smoke' could be an allusion to the unflattering rumours and slanders that are now circulating. The friend is sorry, but Marlowe - and his name - must bear 'the strong offence's cross.' The Marlovian narrative clearly identifies the 'separable spite' which leads the poet to conclude, two sonnets later.

\footnotetext{
'I may not evermore acknowledge thee, Lest my bewailed guilt should do thee shame, Nor thou with public kindness honour me, Unless thou take that honour from thy name: But do not do so...' (36:9-13)
}

If we allow ourselves to imagine that these are private sonnets by Christopher Marlowe, written in exile under a pseudonym that allowed him to communicate with his friend whilst remaining hidden from those who would have him killed - poems successfully attributed for four hundred years to the businessman who agreed to play his front man - we can conclude that the poet's friend and patron heeded those instructions. 
In conclusion, an analysis of Shakespeare's sonnets against two opposing narratives shows what Helen Moore called 'the inherent deceptiveness of a form that seems to be one thing and turns out to be another' (Moore 1999, 229). The use of imagery in the poetry enables us to take an image either literally or metaphorically according to the narrative we are adhering to, changing the way an idea is received or interpreted based on the reading we are either expecting, or imposing. The safest position from which to read the sonnets may therefore appear to be the antibiographical one. But to believe that the sonnets were written largely as a literary exercise, a response to Elizabethan sonnet sequences of the 1590s, also entails taking a certain position on the character of the man who wrote them. Even the least biographical reading implies a particular characterisation of, and therefore a particular narrative for, the author.

Disallowing a Marlovian interpretation of the sonnets as evidence, there is no evidence that Marlowe survived after 1593. There is no evidence Shakespeare attended grammar school, either, yet biographers and scholars routinely assume it, because it is necessary to create a plausible narrative for the author of the works. If we change our frame of reference: if we simply ask the question posed by all fiction, what if? then the extant evidence, from both literary and other primary sources, can be interpreted such that it supports the Marlovian narrative more easily than it supports the orthodox one. Apparent mysteries and inconsistencies in the sonnets are resolved and clarified by reading the text through the lens of this alternative history: suspected ambiguities of tone vanish; paradoxes dissolve; the biographical events behind strong emotions are easily identified; even the poet's friends (and enemies) hove into view.

It has been persuasively argued by leading postmodernist historians, and demonstrated above with respect to Christopher Marlowe, that all narratives are fictive in nature. Yet it has also been demonstrated that the particular biographical 
narrative through which we choose to view the subject of our study will powerfully influence our reading and interpretation of the evidence. If all narrative histories are essentially fictive, how are we to choose between two competing narratives that are mutually exclusive?

The obvious answer - 'plausibility' - is not as simple as it might appear. Though the majority of orthodox scholars doubt the veracity of Marlowe's inquest report, believing that all three witnesses were lying, the consensus remains that what was being covered up was a murder, rather than a faked death. Yet, it is surely plausible that a man might fake his own death in order to escape prosecution on charges which carry the death penalty, if he has the means and opportunity to do so. If his work for the Queen's intelligence services as a projector has led to serious charges being brought against him by Archbishop Whitgift through his allies Lord Buckhurst and Lord Puckering, ${ }^{23}$ who are necessarily unaware of these secret activities, it is equally plausible that his employer Lord Burghley, sanctioned by the Queen, might move to protect him, offering him - as with modern witness protection programmes - a new life under a new identity.

We know it was common for government agents to operate on the continent under assumed names (Kendall 2003, 106). ${ }^{24}$ It is a fact that Lord Burghley, at loggerheads with Whitgift and losing ground to him in terms of Privy Council influence (Sheils 2004), failed to prevent the execution of puritan John Penry at the Archbishop's behest, the day before Marlowe met with Poley, Frizer and Skeres at Deptford (Cross 2004). As Kuriyama points out, the men present with Marlowe at

\footnotetext{
${ }^{23}$ Kendall demonstrates that Lords Buckhurst and Puckering corresponded about the release of Thomas Drury in November 1592, specifically to 'do some servis' and Drury writes to Anthony Bacon in August 1593 that 'there was a command layed on me latly to stay on[e] mr Bayns which did vse to resort vnto me' after which 'ther was by only means sett doun vnto the Lord Keper [and] the L[o]rd of Bucurst the notablyst and vyldist artiyckles of Athemsyme that I suvppose the lyke wer never known or red of in eny age all w[h] I can show vnto you they wer delivered to her hynes' (Kendall 2003, 231-62, 336-37).

${ }_{24}$ Anthony Standen, for example, used the names Monsieur De Faye, Andree Sandal, Saintman, and Pompeio Pelegrini.
} 
widow Bull's house, though known to be expert liars, were not assassins (Kuriyama 2002, 139). The supposed murderer, Ingram Frizer, was a loyal servant of Marlowe's friend and patron Thomas Walsingham. Swiftly pardoned for the killing, Frizer was doing business for Walsingham the very next day, and continued in the service of the Walsinghams to the end of his life, being rewarded by James I with a series of leases in reversion of crown lands (Bakeless 1942, I, 170).

It has been repeatedly demonstrated that those put forward as the instigators of Marlowe's murder have no reason to murder him (Hammer 1996). In any case, were an assassination required, why not simply stab him in a dark alley? Thus Downie and Kuriyama conclude Marlowe was stabbed by accident, as the inquest document states. Still, we are left with questions concerning government involvement at the highest level. Why was a copy of the Baines note sent to the Queen? Why was the heading and content of the note altered in the copy she was given? And what would explain the Queen's curious level of involvement in the case, indicated by her request on Frizer's pardon that 'the jurisdiction remain in our court if anyone should wish to speak against him concerning the above mentioned death' (Kuriyama 2002, 234)?

Discussing the idea that the 'goldsmith' Gifford Gilbert, arrested alongside Marlowe in Flushing, is actually the supposedly dead spy Gilbert Gifford, Kendall notes, "deaths in the murky world of espionage can often be "blinds" for disappearances, and vice versa' (Kendall 2003, 149). But scholarly debate on Marlowe's death considers only two options: either accidental killing in a brawl, or planned murder. The third option of staged death is always dismissed, despite the fact that it would answer the reasonable objections to both the 'murder' and 'brawl' theories. On closer analysis what is implausible is not the deception itself, but the idea that we might have been successfully deceived for four centuries. And yet I contend this is not beyond the realms of possibility. 
Tim Buthe, arguing that narratives have 'distinctive strengths that make them especially suited for historical scholarship', claims that assessing alternative narratives need not be especially problematic once they are 'subjected to the collective assessment of the scholarly community at large' (Buthe 2002, 489). Buthe's qualifier, 'at large', is important. Those considered authorities on Shakespeare necessarily comprise those whose perceptions are anchored in the orthodox narrative, and whose discourse does not, and at present cannot, ${ }^{25}$ (Ankersmit $1988,205)$ entertain any questioning of the authorship of 'Shake-speares Sonnets'. ${ }^{26}$

It was Derrida and Foucault who provoked the first twitches of the linguistic turn which, some forty years ago, began to unravel History's empiricist certainties, separating historiography from history-as-past. As a result, literary theorists created a situation perceived by historians as a significant crisis:

'Now, after a hundred-year absence, literature has returned to history ... demanding that historians accept her mocking presence right at the heart of what they had once insisted was their own autonomous and truly scientific discipline' (Harlan 1989, 581)

Having disturbed the peace of a neighbouring discipline, literature appeared to retire to its own corner; yet the revolution in thinking (or rethinking) history's 'certainties' provoked by literature has now created the potential for further uncertainties in its own discipline; not least the resurrection of an author long thought dead. ${ }^{27}$ Michael North, situating 'the death of the author' as an historical phenomenon arising out of a response to developments in photography and set firmly within the context of the

\footnotetext{
25 '[T]he presuppositions of a discours should,' says Ankersmit, 'be associated with ... what it excludes in the way a taboo excludes certain ways of speaking'.

${ }^{26}$ The name of the author was given in the hyphenated form 'Shake-speare' on the title page and on every verso page of the main text when the sonnets were first published in 1609. Non-Stratfordians have suggested that persistent hyphenation of Shake-speare indicates a pseudonym: disregarding those quartos published anonymously, the name is hyphenated in almost half - 19 out of 40 - of the play quartos published between 1593 and 1630. Randall McCleod's suggestion that hyphenation is due to the need to separate the descenders of the long-k and long-s in kerning fonts does not to stand up to scrutiny. In the case of the 1609 sonnets, Shake-speare is printed in capitals throughout, indicating that hyphenation is a deliberate choice. (Mcleod, R. 1981. Un "Editing" Shak-speare. SubStance 10, no. 4: 26-55.)

${ }^{27}$ Though the parallel with Marlowe is noted, the reference is to Barthes' infamous essay - Barthes, R. 1977. Image, music, text. London: Flamingo, 1984.
} 
French avant-garde movement, arrives at a similar conclusion. Highlighting the metaphors employed by authors who might have expected obliteration both by their own texts and the texts written about them, he observes it is 'as if human creativity has been captured, and fixed all the more securely in time and space, by its own inventions.'(North 2001, 1384)

The sense of coming full circle, disconcerting to those literary scholars more comfortable with texts divorced from their authors, is an illusion, since there is forward intellectual momentum as we revise and refine our understanding of the roles of both author and reader. A community of scholars ensures that relative stasis in one discipline will be disturbed by movement in another; so literature and history inform each other's philosophies. Those who re-approach the stirring author do so from within a new paradigm, both armed and disarmed by the knowledge that they, too, are authors.

There is growing conviction across the humanities that Barthes' proclamation was not just premature, but mistaken. Recent debates in Shakespearean attribution studies illustrate that authorship remains vitally important (Foster 1988; 1997; Monsarrat 2002; Vickers 2002), and that even when biographical interpretation of texts is overtly avoided, biographical arguments, quite correctly, play a significant role in determining the acceptability of an attribution (Abrams 2002; Duncan-Jones $1997 b) .^{28}$

If Barthes' all-encompassing 'author', obliterated from the picture by the endless texts written after and about him, is the figurative representation; Christopher Marlowe may yet prove to be the literal exemplar. As illustrated recently in the UK

\footnotetext{
${ }^{28}$ The attribution of 'A Funeral Elegy' by 'W.S.' was argued largely on the basis of computer-aided stylometric analysis, in an attempt to minimise subjectivity, but biographical arguments were also advanced both for and against the attribution to Shakespeare.
} 
by the 'dead' canoeist John Darwin, you might believe a person dead, he might officially be declared so, but neither of these conditions means he is. Our beliefs are not the reflections of reality; they are the creators of it.

\section{Bibliography}

Abrams, R. 2002. Meet the Peters. Early Modern Literary Studies 8.2: 6: 1-39.

Acheson, A. 1903. Shakespeare and the rival poet, displaying Shakespeare as a satirist and proving the identity of the patron and the rival of the sonnets, [with the Earl of Southampton and George Chapman] ... With a reprint of sundry poetical pieces by George Chapman bearing on the subject. London \& New York: John Lane.

Ankersmit, F.R. 1988. Historical representation. History and Theory 27, no. 3: 20528.

Ankersmit, F.R. 1989. Historiography and postmodernism. History and Theory 28, no. 2 : $137-53$.

Aubrey, J. and A. Clark. 1898. Brief lives chiefly of contemporaries : Set down by John Aubrey, between the years 1669 \& 1696. 2 vols. Oxford: Clarendon Press.

Bakeless, J.E. 1942. The tragicall history of Christopher Marlowe. Vol. I of. 2 vols. Cambridge: Harvard University Press.

Barthes, R. 1977. Image, music, text. London: Flamingo, 1984.

Bate, J. 2007. A man for all ages. The Guardian 14.04.07, Review section.

Beard, T. 1597. The theatre of God's judgements. London: Adam Islip. 
Buthe, T. 2002. Taking temporality seriously: Modeling history and the use of narratives as evidence. The American Political Science Review 96, no. 3: 48193.

Camden, W. and A. Darcie. 1625. Ed. Vaughan, R. Annales the true and royall history of the famous empresse Elizabeth Queene of England. Early english books, 1475-1640 / 877:05. London: Printed [by George Purslowe, Humphrey Lownes, and Miles Flesher] for Beniamin Fisher.

Chapman, G. 1941. Ed. Bartlett, Pb. The poems of George Chapman. London: Oxford University Press.

Cross, C. 2004. Penry, John (1562/3-1593). Oxford: OUP.

Duncan-Jones, K. ed. 1997a. Shakespeare's sonnets. Arden Shakespeare, Thomson Learning.

Duncan-Jones, K. 1997b. Who wrote a funerall elegie? Shakespeare Studies (Madison, NJ): 192.

Edmondson, P. and S.W. Wells. 2004. Shakespeare's sonnets Oxford shakespeare topics. Oxford ; New York: Oxford University Press.

Erne, L. 2003. Shakespeare as literary dramatist. Cambridge, UK ; New York: Cambridge University Press.

Foster, D.W. 1988. Elegy by W.S. : A study in attribution. University of Delaware Press ; London : Associated University Presses.

Foster, D.W. 1997. A funeral elegy: W(illiam) S(hakespeare)'s "Best-speaking witnesses". Shakespeare Studies (Madison, NJ): 115.

Gadamer, H.G. 1989. Truth and method. 2nd rev. ed. / translation revised by Joel Weinsheimer and Donald G. Marshall. ed. London: Sheed and Ward. Hammer, P., E. J. 1996. A reckoning reframed: The "Murder" of Christopher Marlowe revisited. English Literary Renaissance 26, no. 2: 225-42. 
Hanson, E. 1991. Torture and truth in Renaissance England. Representations, no. 34: 53-84.

Harlan, D. 1989. Intellectual history and the return of literature. The American Historical Review 94, no. 3: 581-609.

Honan, P. 2005. Christopher Marlowe : Poet \& spy. Oxford ; New York: Oxford University Press.

Honigmann, E.A.J. 1982. Shakespeare's impact on his contemporaries. Totowa, NJ: Barnes \& Noble Books.

Jenkins, K. 1991. Re-thinking history. London: Routledge.

Kendall, R. 2003. Christopher Marlowe and Richard Baines : Journeys through the elizabethan underground. Madison, N.J.: Fairleigh Dickinson University Press; London: Associated University Presses.

Kuriyama, C.B. 2002. Christopher Marlowe : A renaissance life. Ithaca, London: Cornell University Press.

Maclure, M. 1979. Christopher Marlowe: The critical heritage. London: Routledge. Mcleod, R. 1981. Un "Editing" Shak-speare. SubStance 10, no. 4: 26-55.

Meres, F. 1598. Palladis tamia. Wits treasury being the second part of wits common wealth. . London: P. Short for Cuthbert Burbie.

Minto, W. 1874. Characteristics of English poets from Chaucer to Shirley. Edinburgh, London: William Blackwood.

Monsarrat, G.D. 2002. A funeral elegy: Ford, W.S., and Shakespeare. Review of English Studies 53, no. 210: 186-203.

Moore, H. 1999. Review of R.W.Maslen's "Elizabethan fictions: Espionage, counterespionage, and the duplicity of fiction in early Elizabethan prose narratives." The Review of English Studies 50, no. 198: 228-29.

Munslow, A. 1997. Deconstructing history. London: Routledge. 
Nicholl, C. 2002. The reckoning : The murder of Christopher Marlowe. Revised ed. London: Vintage.

North, M. 2001. Authorship and autography. PMLA 116, no. 5: 1377-85.

Oakeshott, M. 1983. On history : And other essays. Oxford: Blackwell.

Price, D. 2001. Shakespeare's unorthodox biography: New evidence of an authorship problem. Contributions in drama \& theatre studies. Conneticut, London: Greenwood Press.

Riggs, D. 1989. Ben Jonson : A life. Cambridge, Mass.: Harvard University Press.

Riggs, D. 2004. The world of Christopher Marlowe. London: Faber and Faber.

Robertson, J.M. 1926. The problems of the Shakespeare sonnets. London: G. Routledge \& Sons.

Rudierde, E. 1618. The thunderbolt of gods wrath against hard-hearted and stiffenecked sinners, or an abridgement of the theater of gods fearefull judgements executed upon notorious sinners: W.I. by the Assignement of A. Islip.

Shagan, E.H. 2004. The English inquisition: Constitutional conflict and ecclesiastical law in the1590s. The Historical Journal 47, no. 03: 541-65.

Sheils, W.J. 2004. Whitgift, John (1530/31?-1604). Oxford: OUP.

Slotkin, R. 2005. Fiction for the purposes of history. Rethinking History 9, no. 2: 221 $-36$.

Southgate, B. 2005. In search of Ariadne's thread. Rethinking History 9, no. 1: 91 104.

Southgate, B. 2006. A pair of white gloves: Historians and ethics. Rethinking History 10, no. 1: $49-61$.

Topolski, J. 1999. The role of logic and aesthetics in constructing narrative wholes in historiography. History and Theory 38, no. 2: 198-210. 
Vaughan, W.P. 1608. The golden-grove, moralized in three bookes ... Second edition, ... Enlarged by the authour: E. Stafford: London.

Vickers, B. 2002. Counterfeiting Shakespeare : Evidence, authorship and John Ford's funerall elegye. Cambridge: Cambridge University Press.

Webster, A. 1923. Was Marlowe the man? The National Review LXXXII: 81-86.

Weis, R. 2007. Shakespeare revealed : A biography. London: John Murray.

White, H. 1973. Metahistory : The historical imagination in nineteenth-century europe. Baltimore ; London: Johns Hopkins University Press.

White, H. 1978. Tropics of discourse : Essays in cultural criticism. Baltimore ; London: John Hopkins University Press.

Wraight, A.D. 1994. The story that the sonnets tell. London, UK: Adam Hart.

Wraight, A.D. and V.F. Stern. 1965. In search of Christopher Marlowe; a pictorial biography. London: Macdonald. 